\title{
Bacterial Contamination of Hospital Equipments in Two Tertiary Health Facilities in Central Nigeria and Their Corresponding Susceptibility to Antimicrobial Agents
}

\author{
Adamu Muktar Owuna', Owuna Jibril Egwu', Yakubu Akuki Hajara1, Azamu Ibaku Gowon² \\ ${ }^{1}$ Department of Microbiology, Nasarawa State University, Keffi, Nigeria \\ ${ }^{2}$ Department of Biology, Nigerian Army University, Biu, Nigeria
}

Email address:

adamuowuna $@$ gmail.com (A. M. Owuna)

\section{To cite this article:}

Adamu Muktar Owuna, Owuna Jibril Egwu, Yakubu Akuki Hajara, Azamu Ibaku Gowon. Bacterial Contamination of Hospital Equipments in Two Tertiary Health Facilities in Central Nigeria and Their Corresponding Susceptibility to Antimicrobial Agents. International Journal of Biomedical Engineering and Clinical Science. Vol. 5, No. 2, 2019, pp. 24-30. doi: 10.11648/j.ijbecs.20190502.13

Received: August 21, 2019; Accepted: September 6, 2019; Published: September 25, 2019

\begin{abstract}
Hospital is a major avenue for the spread of infectious diseases known as nosocomial infections. This study investigated the bacteria that colonize hospital equipments at the Federal Medical Centre and Nasarawa State University Clinic Keffi. Swab samples of different hospital equipments were collected and examined using standard microbiological techniques. Cultural features indicates the presence of the following bacteria; Escherichia coli, Klebsiella spp., Pseudomonas spp., Staphylococcus aureus and Enterobacter spp. The mean bacterial load from NSUK clinic equipments $\left(\times 10^{4} \mathrm{cfu} / \mathrm{ml}\right)$ were 0.32 , $0.18,0.19$ and 0.1 for total viable, total coliform, total fecal coliform and staphylococcus aureus count respectively, while the mean bacterial load in FMC $\left(\times 10^{4} \mathrm{cfu} / \mathrm{ml}\right)$ was $1.254,0.347$ and 0.283 for total viable count, coliform count and faecal coliform count accordingly. Frequency of occurrence of the bacteria isolates in FMC is in the order: Escherichia coli $(50.0 \%)>$ Enterobacter spp. $(30.0 \%)>$ Klebsiella spp. and Pseudomonas spp. $(20.0 \%)>$ Staphylococcus aureus $(0.0 \%)$; while that of NSUK clinic is in the order: Escherichia coli $(50.0 \%)>$ Pseudomonas spp. (30.0\%)>Staphylococcus aureus $(10.0 \%)$, while Klebsiella spp. and Enterobacter spp. were not isolated at NSUK clinic. The antibiotic susceptibility pattern of the bacteria showed Pseudomonas spp. to be completely susceptible to Augmentin, Gentamicin, Chloramphenicol and Ciprofloxacin (100.0\% each), while E. coli showed some degree of susceptibility to Streptomycin (44.4\%), Ciprofloxacin and Perfloxacin (33.3\%), Gentamicin and Sparfloxacin (22.2\%), Augmentin, Ofloxacin, Septrin and Chloramphenicol (11.1\%), but completely resistant to Amoxicillin. Klebsiella spp. and Enterobacter spp. were resistant to all the antibiotics tested, except for Streptomycin which they displayed high susceptibility of $100.0 \%$ and $66.7 \%$ for Klebsiella spp. and Enterobacter spp. respectively. Staphylococcus aureus was found to be resistant completely against all the antibiotics tested. Hence, it is pertinent to embrace hand hygiene so as to minimize the risk of acquiring nosocomial infections due to contaminated hospital equipments.
\end{abstract}

Keywords: Bacteria, Hospital Equipments, Antibiotic Susceptibility, Keffi, Nigeria

\section{Introduction}

Contamination of hospital equipment, medicines, and water supplies with hospital pathogens is a well-recognized cause of common-source outbreaks of infection [1, 2]. Extensive guidance on the prevention and control of such contamination is available from manufacturers, specialist societies, and health departments, and there is often a legal requirement to comply with associated health and safety regulations. In contrast, the degree to which ongoing contamination of the surface environment contributes to the development of health-care-associated infections is unclear, and approaches to control are uncertain [2]. Bacterial contamination of hospital equipments is one of the most probable cause of nosocomial infections. These infections are developed within a hospital or other type of clinical care facility and are acquired by patients while they are in the facility $(3,4)$.

More so, besides harming patients, nosocomial infections 
can affect nurses, physicians, aides, visitors, delivery person, custodians and anyone who has contact with the hospital. The Center for Disease Control (CDC) estimates that about 10\% of all hospital patients acquire some type of nosocomial infection as a result of contact with some contaminated hospital equipment. Approximately 40 million people are admitted to hospitals annually, 2 to 4 million people may develop an infection they did not have upon entering the hospital. Thus, nosocomial infections represent a significant proportion of all infectious diseases acquired by humans (4). The contamination of some equipment commonly in use during arthroplasty, including the collection bag used during hip replacement and the 'sterile' handles attached to the theatre lights, has not been explored. The bags are often used as a resting place for instruments and swabs during surgery, a habit which may facilitate transfer of bacteria into the wound. The light handles are attached to an unsterile light which, by its size, probably disturbs the laminar flow and creates eddies of air around it. The handle may also be inadvertently touched by the unclean heads of scrubbed personnel (5).

Generally, hospital patients shed pathogens into their surrounding environments, but there is debate over the importance of the resulting surface contamination as a source for subsequent transmission. Since the 1950s, hospital design and hygienic practices have been largely directed at controlling nosocomial pathogens contaminating air, hands, equipment, and surfaces $(2,6)$. An infection is regarded as nosocomial if it is as a result of treatment in a hospital or hospital-like setting, but secondary to the patient's original condition and manifests 48 hours or more after hospital admission or within 30 days after discharge (7). Nosocomial pathogens and infection are relatively common because hospitals receive large number of patients, some of whom may be immunocompromised. Nosocomial pathogens and by extension the resulting infectious disease can complicate and prolong hospital admission $(7,8)$.

Schwegman (9) opined that hospital acquired infections (HAIs) are the result of a high prevalence of pathogens with a high prevalence of susceptible hosts and efficient transmission mechanisms from patient to patient. Unfortunately, these pathogens tend to become incorporated into the normal flora of hospital workers and are readily transmitted through direct contact transmission, although, less common, medical devices such as sphygmomanometers, thermometers, and stethoscopes have been implicated in the spread of HAI's through indirect contact transmission. Multi reservoirs have been reported as being responsible for hospital contamination particularly due to stethoscope, in the delivery theatre and intensive care units (ICU) $(4,10)$. Inglis (11) listed nosocomial bacteria which include Staphylococcus aureus, Pseudomonas aeruginosa, Klebsiella spp., Enterococcus spp, Citrobacter spp, Acinobacter spp, Yersina enterolitica, Treponema pallidium, Mycobacterium tuberculosis, coagulase-negative staphylococci (epidermidis and saprophyticus) and coliform spp. These microorganisms are associated with hands of medical staff and paramedics, hospital equipment and accessories such as patient support systems, couch, x-ray cassettes (13) and changing gowns (7, 12).

In fact, stethoscopes were first identified as potential vectors for bacterial infection over 30 years ago (14). Both the diaphragm and earpieces of physician's personal stethoscopes and bedside stethoscopes are frequently colonized with a variety of pathogenic organisms including methicillin-resistant Staphylococcus aureus (MRSA) and vancomycin-resistant enterococci (VRE) which cause significant morbidity and mortality on the intensive care unit (ICU) as reported by several authors such as Jones et al. (15), Bernard et al. (16), Zachary et al. (17), Cohen et al. (18) and Whittington et al. (14). Based on Centers for Disease Control and Prevention (CDC) classification, medical and surgical instruments are categorized to "critical," "semi critical" and "non-critical" (19). More so, environmental surfaces can be further divided into medical equipment surfaces (e.g., knobs or handles on hemodialysis machines, X-ray machines, instrument carts, and dental units) and housekeeping surfaces (e.g., floors, walls, and tabletops) $(19,20)$. This research is therefore aimed at isolating and identifying bacterial pathogens that contaminates hospital equipments thereby putting patients at risk of acquiring nosocomial infections.

\section{Materials and Methods}

\section{Study Area}

This work was carried out in the Microbiology Laboratory of the Department of Microbiology, Nasarawa State University Keffi. Keffi is located in the middle belt of Nigeria. It is geographically situated on a latitude $8^{\circ} 5^{\circ} \mathrm{N}$ and longitude $7^{\circ} 52^{\circ} \mathrm{E}$. Keffi town is on longitude 850 above sea level and it is the North-West of Lafia, the state capital of Nasarawa State. It is $53 \mathrm{~km}$ away from Abuja (Capital of Nigeria) in the Guinea Savannah region of Nigeria (21).

\section{Sampling Procedure}

Federal Medical Centre (FMC) and Nasarawa State University clinic (NSUK) were selected for the purpose of this work. A total of twenty (20) samples were collected using moistened sterile cotton swabs. The following equipments were sampled at FMC; kidney dish, exposure botton, x-ray tube, surgical knife, artery forcep, x-ray couches, dissecting, forcep, thermometer, chest stand, stethoscope; while laboratory scissors, scissors from nursing unit, laboratory forcep, laboratory bench, female ward sink, haemotospin, nursing unit forcep, male ward sink, thermometer and hand washing basin were sampled at NSUK clinic. The samples were transported immediately to the Microbiology Laboratory of the Microbiology Department, Nasarawa State University, Keffi.

\section{Sample Preparation}

The swabs were introduced into $9 \mathrm{ml}$ of sterile water in test tubes, it was washed and shake rigorously, and from which a 10 -fold serial dilution was carried out to achieve $10^{-5}$ dilution.

Isolation of Bacteria

Pour plate method was used for the inoculation of the 
samples. After carrying out the 10 -fold serial dilution, $0.1 \mathrm{ml}$ of the diluents samples were poured in duplicate on sterile petri dishes after which freshly prepared Nutrient Agar, MacConkey Agar, Eosine Methylene Blue Agar and Mannitol Salt Agar were introduced for total viable count, total coliform count, total faecal coliform count and Staphylococcus aureus count respectively. The plates were incubated at $37^{\circ} \mathrm{C}$ for 24 hours. After $24 \mathrm{hrs}$, the colonies were counted and expressed as colony forming units per millimeters $(\mathrm{cfu} / \mathrm{ml})$.

\section{Identification of Bacterial Isolates}

Different colonies that grew on the respective media were sub-cultured on Nutrient agar to obtain discrete colonies. These isolates were further classified using morphological, microscopic and biochemical tests. The characterization was done according to the methods of Cheesbrough (22).

\section{Antibiotic Susceptibility Test}

The bacterial isolates were screened for antimicrobial susceptibility using the Kirby-Bauer agar disk diffusion method (23). Briefly, a suspension of each isolate was prepared in peptone water to match $0.5 \mathrm{McFarland}$ turbidity standards. The standardized inoculum of each isolate was then separately inoculated in triplicates onto the surfaces of plain Mueller-Hinton agar plates and Amoxicillin $(30 \mu \mathrm{g})$, Augmentin $(30 \mu \mathrm{g})$, Gentamicin $(10 \mu \mathrm{g})$, Perfloxacin $(10 \mu \mathrm{g})$, Ofloxacin $(10 \mu \mathrm{g})$, Streptomycin $(30 \mu \mathrm{g})$, Septrin $(30 \mu \mathrm{g})$,

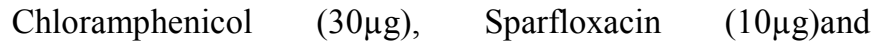
Ciprofloxacin $(10 \mu \mathrm{g})$, discs were placed aseptically and incubated at $37^{\circ} \mathrm{C}$ for $24 \mathrm{hrs}$; after which the zones of inhibition were measured using a metre rule and compared with the standards of the Clinical and Laboratory Standards Institute guidelines (24).

\section{Results}

This study determines the bacteria contaminants that colonize hospital equipments at the Federal Medical Centre and Nasarawa State University Clinic Keffi and also tested their antibiotic susceptibility pattern against some common antibiotics. Cultural, morphological and biochemical characteristics of the isolates revealed the presence of the following bacteria; Escherichia coli, Klebsiella spp., Pseudomonas spp., Staphylococcus aureus and Enterobacter spp. (Table 1). The bacterial load as enumerated from samples at NSUK clinic indicates the total viable count, total coliform count, total faecal coliform count and staphylococcus count to ranged between $0.2-0.9 \times 10^{4} \mathrm{cfu} / \mathrm{ml}$,
$0.2-0.6 \times 10^{4} \mathrm{cfu} / \mathrm{ml}, \quad 0.1-0.8 \times 10^{4} \mathrm{cfu} / \mathrm{ml}$ and $0.9 \times 10^{4} \mathrm{cfu} / \mathrm{ml}$ respectively. Similarly, the mean bacterial load from NSUK clinic equipments $\left(\times 10^{4} \mathrm{cfu} / \mathrm{ml}\right)$ were $0.32,0.18,0.19$ and 0.1 for total viable, total coliform, total fecal coliform and staphylococcus aureus count respectively (Table 2). Similarly, the bacterial load from the equipments of FMC showed the total viable, total coliform, total fecal coliform and staphylococcal aureus count to ranged between $1.0-1.9 \times$ $10^{4} \mathrm{cfu} / \mathrm{ml}, 0.1-0.9 \times 10^{4} \mathrm{cfu} / \mathrm{ml}, 0.1-0.8 \times 10^{4} \mathrm{cfu} / \mathrm{ml}$, and no staphylococcal was counted for FMC equipments respectively. The mean bacterial load in FMC $\left(\times 10^{4} \mathrm{cfu} / \mathrm{ml}\right)$ was $1.254,0.347$ and 0.283 for total viable count, coliform count and faecal coliform count accordingly (Table 3 ).

The rate of isolation of the bacteria from the equipments in FMC indicates that $E$. coli is the most occurring bacteria contaminant with a percentage isolation of $50.0 \%$, followed by Enterococci spp. (30.0\%), Klebsiella spp. and Pseudomonas spp. (20.0\%), while Staphylococcus aureus was absent in FMC (Table 4). Similarly, the rate of isolation of the bacteria contaminants from NSUK clinic showed that E. coli (50.0\%), Pseudomonas spp. (30.0\%) and Staphylococcus aureus (10.0\%) are the most isolated bacteria while Klebsiella spp. and Enterococci spp. were found to be absent from the equipments sampled at NSUK clinic (Table 5). The antibiotic susceptibility pattern of the bacteria isolated display varying susceptibility/resistance to the antibiotics tested and was presented in Table 6. Pseudomonas spp. and Escherichia coli showed the highest susceptibility to most of the tested antibiotics; Pseudomonas spp. for instance was found to be completely susceptibility Augmentin, Gentamicin, Chloramphenicol and Ciprofloxacin (100.0\% each), while the isolates were intermediately susceptible to Amoxicillin, Ofloxacin, Streptomycin, and Sparfloxacin (50.0\% each), but was found to be completely resistant to Perfloxacin. E. coli on the other hand was only slightly susceptible to the antibiotics tested; E. coli showed some degree of susceptibility to Streptomycin (44.4\%), Ciprofloxacin and Perfloxacin (33.3\%), Gentamicin and Sparfloxacin (22.2\%), Augmentin, Ofloxacin, Septrin and Chloramphenicol (11.1\%), but completely resistant to Amoxicillin. Klebsiella spp. and Enterobacter spp. were resistant to all the antibiotics tested, except for Streptomycin which they displayed high susceptibility of $100.0 \%$ and $66.7 \%$ for Klebsiella spp. and Enterobacter spp. respectively. Staphylococcus aureus was found to be resistant completely against all the antibiotics tested.

Table 1. Cultural, morphological and biochemical characteristics of the bacterial isolated from some hospital equipments in FMC and NSUK clinic.

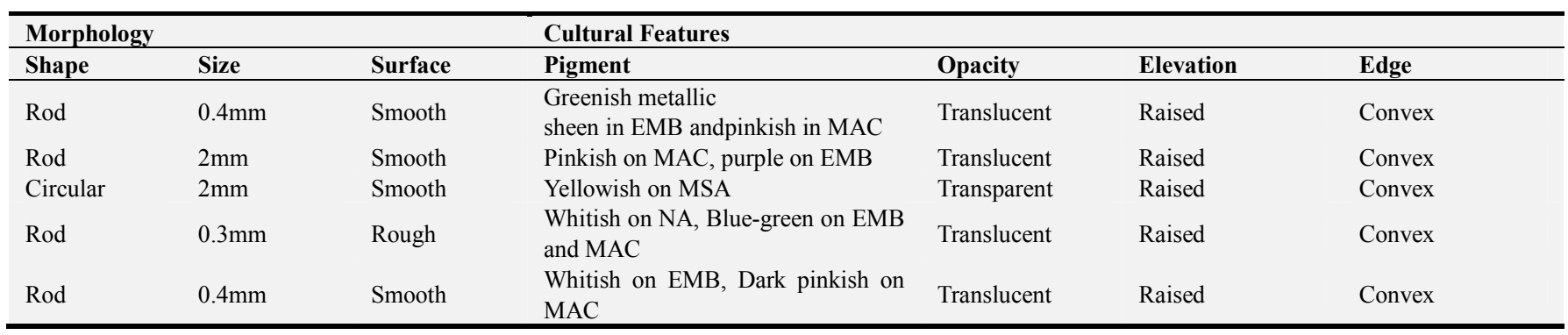


Table 1. Continued.

\begin{tabular}{|c|c|c|c|c|c|c|c|c|}
\hline \multicolumn{9}{|c|}{ Biochemical Characteristics } \\
\hline G.S & IN & CAT & COA & $\mathbf{O X}$ & MR & VP & CT & Probable Isolates \\
\hline- & + & + & - & - & + & - & - & E. coli \\
\hline- & - & + & - & - & - & + & + & Klebsiella spp. \\
\hline+ & - & + & + & - & + & - & - & Staph. aureus \\
\hline- & - & + & - & + & - & - & + & Pseudomonas spp. \\
\hline- & - & + & - & - & - & + & + & Enterobacter spp. \\
\hline
\end{tabular}

Key: $\mathrm{NA}=$ Nutrient agar, $\mathrm{MAC}=\mathrm{MacConkey}$ agar, $\mathrm{EMB}=$ Eosine Methylene Blue agar, $\mathrm{IND}=\mathrm{Indole}, \mathrm{MR}=\mathrm{Methyl}$ red, $\mathrm{CAT}=\mathrm{Catalase}, \mathrm{COA}=\mathrm{Coagulase}$, $\mathrm{OX}=$ Oxidase, $\mathrm{VP}=$ Voges Proskauer, $\mathrm{MSA}=$ Manitol Salt agar, G.S= Gram staining, $\mathrm{CT}=\mathrm{Citrate},-=$ negative,$+=$ positive

Table 2. Bacterial load of hospital equipments used in FMC Keffi $\left(\times 10^{4}\right.$ $c f u / m l)$.

\begin{tabular}{lllll}
\hline Sample & TVC & TCC & TFC & SC \\
\hline Kidney dish & 1.9 & 0.9 & 0.4 & - \\
Exposure botton & 1.6 & 0.6 & 0.3 & - \\
X-ray tube & 1.3 & 0.4 & 0.6 & - \\
Surgical knife & 1.7 & 0.7 & 0.3 & - \\
Artery forcep & 1.0 & 0.2 & - & - \\
X-ray couches & 1.8 & 0.3 & 0.8 & - \\
Dissecting forcep & 1.4 & 0.1 & 0.4 & - \\
Thermometer & 2.0 & 0.2 & 0.1 & - \\
Chest stand & - & - & - & - \\
Stethoscope & - & - & - & - \\
Mean & 1.254 & 0.347 & 0.283 & \\
\hline
\end{tabular}

Key: $\quad$ TVC $=$ Total viable count, $\mathrm{TCC}=$ Total coliform count, $\mathrm{SC}=$ Staphylococcal count, TFC $=$ Total fecal coliform count
Table 3. Bacterial load of hospital equipments used in NSUK clinic $\left(\times 10^{4}\right.$ cfu/ml).

\begin{tabular}{lllll}
\hline Sample & TVC & TCC & TFC & SC \\
\hline Laboratory Scissors & 0.8 & 0.2 & - & - \\
Nursing unit scissor & 0.5 & 0.4 & 1.2 & 0.9 \\
Laboratory forcep & 0.4 & 0.3 & 0.1 & - \\
Laboratory work bench & 0.2 & 0.4 & 0.4 & - \\
Female ward sink & 0.3 & 0.6 & 0.8 & - \\
Haematospin & 0.9 & 0.2 & 0.5 & - \\
Nursing unit forcep & - & - & - & - \\
Male ward sink & - & - & - & - \\
Thermometer & - & - & - & - \\
Hand washing basin & - & - & - & - \\
Mean & 0.3 & 0.188 & 0.198 & 0.09
\end{tabular}

Key: $\quad$ TVC $=$ Total viable count,$\quad \mathrm{TCC}=$ Total coliform count, $\mathrm{SC}=$ Staphylococcal count, $\mathrm{TFC}=$ Total fecal coliform count

Table 4. Percentage occurrence of the bacteria isolates from some hospital equipments in FMC.

\begin{tabular}{|c|c|c|c|c|c|}
\hline Samples (n) & $\begin{array}{l}\text { Escherichia } \\
\text { coli }(\%)\end{array}$ & $\begin{array}{l}\text { Klebsiella } \\
\text { spp. }(\%)\end{array}$ & $\begin{array}{l}\text { Pseudomonas } \\
\text { spp.(\%) }\end{array}$ & $\begin{array}{l}\text { Enterobacter } \\
\text { spp. }(\%)\end{array}$ & $\begin{array}{l}\text { Staphylococcus } \\
\text { aureus(\%) }\end{array}$ \\
\hline Kidney dish (1) & $1(100.0)$ & $0(0.0)$ & $0(0.0)$ & $1(100.0)$ & $0(0.0)$ \\
\hline Exposure botton (1) & $1(100.0)$ & $0(0.0)$ & $0(0.0)$ & $0(0.0)$ & $0(0.0)$ \\
\hline X-ray tube (1) & $1(100.0)$ & $0(0.0)$ & $1(100.0)$ & $0(0.0)$ & $0(0.0)$ \\
\hline Surgical knife (1) & $1(100.0)$ & $0(0.0)$ & $1(100.0)$ & $0(0.0)$ & $0(0.0)$ \\
\hline Artery forcep (1) & $0(0.0)$ & $1(100.0)$ & $0(0.0)$ & $1(100.0)$ & $0(0.0)$ \\
\hline X-ray couches (1) & $0(0.0)$ & $1(100.0)$ & $0(0.0)$ & $0(0.0)$ & $0(0.0)$ \\
\hline Dissecting forcep (1) & $1(100.0)$ & $0(0.0)$ & $0(0.0)$ & $1(100.0)$ & $0(0.0)$ \\
\hline Thermometer (1) & $0(0.0)$ & $0(0.0)$ & $0(0.0)$ & $0(0.0)$ & $0(0.0)$ \\
\hline Stethoscope (1) & $0(0.0)$ & $0(0.0)$ & $0(0.0)$ & $0(0.0)$ & $0(0.0)$ \\
\hline Chest stand (1) & $0(0.0)$ & $0(0.0)$ & $0(0.0)$ & $0(0.0)$ & $0(0.0)$ \\
\hline Total (10) & $5(50.0)$ & $2(20.0)$ & $2(20.0)$ & $3(30.0)$ & $0(0.0)$ \\
\hline
\end{tabular}

$\mathrm{n}=$ Number of samples

Table 5. Percentage occurrence of the bacteria isolates from some hospital equipments in NSUK clinic.

\begin{tabular}{|c|c|c|c|c|c|}
\hline Samples (n) & $\begin{array}{l}\text { Escherichia } \\
\text { coli }(\%)\end{array}$ & $\begin{array}{l}\text { Pseudomonas } \\
\text { spp. (\%) }\end{array}$ & $\begin{array}{l}\text { Klebsiella } \\
\text { spp.(\%) }\end{array}$ & $\begin{array}{l}\text { Enterobacter } \\
\text { spp. }(\%)\end{array}$ & $\begin{array}{l}\text { Staphylococcus } \\
\text { aureus(\%) }\end{array}$ \\
\hline Scissors (2) & $0(0.0)$ & $2(100.0)$ & $0(0.0)$ & $0(0.0)$ & $1(50.0)$ \\
\hline Forcep (2) & $2(100.0)$ & $0(0.0)$ & $0(0.0)$ & $0(0.0)$ & $0(0.0)$ \\
\hline Lab work bench (1) & $1(100.0)$ & $0(0.0)$ & $0(0.0)$ & $0(0.0)$ & $0(0.0)$ \\
\hline Sink (2) & $1(50.0)$ & $1(50.0)$ & $0(0.0)$ & $0(0.0)$ & $0(0.0)$ \\
\hline Haematospin (1) & $1(100.0)$ & $0(0.0)$ & $0(0.0)$ & $0(0.0)$ & $0(0.0)$ \\
\hline Hand washing basin (1) & $0(0.0)$ & $0(0.0)$ & $0(0.0)$ & $0(0.0)$ & $0(0.0)$ \\
\hline Total (10) & $5(50.0)$ & $3(30.0)$ & $0(0.0)$ & $0(0.0)$ & $1(10.0)$ \\
\hline
\end{tabular}

$\mathrm{n}=$ Number of samples 
Table 6. Antibiotic susceptibility of bacteria isolates from some hospital equipments in FMC and NSUK clinics (\%).

\begin{tabular}{lllllll}
\hline Antibiotics & Conc. & $\begin{array}{l}\text { Escherichia } \\
\text { coli (9) }\end{array}$ & $\begin{array}{l}\text { Pseudomonas } \\
\text { spp. (2) }\end{array}$ & $\begin{array}{l}\text { Klebsiella } \\
\text { spp. (2) }\end{array}$ & $\begin{array}{l}\text { Enterobacter } \\
\text { spp. (3) }\end{array}$ & $\begin{array}{l}\text { Staphylococcus } \\
\text { aureus (1) }\end{array}$ \\
\hline Amoxicillin & $30 \mu \mathrm{g}$ & $0(0)$ & $1(50.0)$ & $0(0.0)$ & $0(0.0)$ & $0(0.0)$ \\
Augmentin & $30 \mu \mathrm{g}$ & $1(11.1)$ & $2(100.0)$ & $0(0.0)$ & $0(0.0)$ & $0(0.0)$ \\
Gentamicin & $10 \mu \mathrm{g}$ & $2(22.2)$ & $2(100.0)$ & $0(0.0)$ & $0(0.0)$ & $0(0.0)$ \\
Perfloxacin & $10 \mu \mathrm{g}$ & $3(33.3)$ & $0(0.0)$ & $0(0.0)$ & $0(0.0)$ & $0(0.0)$ \\
Ofloxacin & $10 \mu \mathrm{g}$ & $1(11.1)$ & $1(50.0)$ & $0(0.0)$ & $0(0.0)$ & $0(0.0)$ \\
Streptomycin & $30 \mu \mathrm{g}$ & $4(44.4)$ & $1(50.0)$ & $2(100.0)$ & $2(66.7)$ & $0(0.0)$ \\
Septrin & $30 \mu \mathrm{g}$ & $1(11.1)$ & $1(50.0)$ & $0(0.0)$ & $0(0.0)$ & $0(0.0)$ \\
Chloramphenicol & $30 \mu \mathrm{g}$ & $1(11.1)$ & $2(100.0)$ & $0(0.0)$ & $0(0.0)$ & $0(0.0)$ \\
Sparfloxacin & $10 \mu \mathrm{g}$ & $2(22.2)$ & $1(50.0)$ & $0(0.0)$ & $0(0.0)$ & $0(0.0)$ \\
Ciprofloxacin & $10 \mu \mathrm{g}$ & $3(33.3)$ & $2(100.0)$ & $0(0.0)$ & $0(0.0)$ & $0(0.0)$ \\
\hline
\end{tabular}

\section{Discussion and Conclusion}

The hospital environment is contaminated with a variety of pathogenic and nonpathogenic microorganisms that can persist on surfaces for prolonged periods. Numerous studies have demonstrated that the hands and gloves of healthcare workers readily acquire pathogens after coming into contact with contaminated hospital surfaces and they can subsequently transfer these organisms to the patients and inanimate surfaces that they touch $(2,7,9,19,25-29)$. Prehospital procedures such as intravenous cannulation, parenteral injections, needle thoracentesis and endotracheal intubation are common source of contamination of hospital equipments, due in part, to exposure of the equipments by potentially infectious fluids which are often uncontrollable (30). This study demonstrates the colonization and contamination of hospital equipment by bacteria in two hospitals in Keffi, Nigeria.

The following bacterial pathogens were found to contaminate the hospital equipments examined in this present study; Escherichia coli, Pseudomonas spp., Klebsiella spp., Enterobacter spp. and Staphylococcus aureus. Several researchers have found similar isolates to contaminate hospital in different parts of the world (27, 31-34). Generally, while Kayabas et al. (33) has demonstrated earlier that the presence of bacteria is common in inanimate surfaces and equipment, their presence poses public health risk due to the possibility of transmission of nosocomial infections. This study observed the laboratory scissors to be more contaminated with the bacteria isolated in NSUK clinic which conforms to the work of Embil et al. (8), while kidney dish was more loaded with bacteria at FMC. Cordeiro et al. (35) examined hospital equipments for possible contamination by microorganisms in a hospital environment in Brazil and reports comparable bacteria load to those reported in this particular study.

Escherichia coli, Enterobacter spp. and Pseudomonas spp. were found to be the most occurring bacterial contaminants. Thus hospital equipments induced nosocomial infections is likely ongoing because of the high risk of contact of patients with the hospital-based equipments. Also, bacterial contamination of equipments in health care settings is likely ongoing as organisms such as Staphylococci, E. coli, and $P$. aeruginosa survive at least 3-6 months on dried blood or cotton and as long as four weeks on other surfaces (36). This perhaps accounts for the high isolation rate of these bacteria. Earlier, Kim and coworkers (37) reported E. coli to be the most common gram-negative bacterium, causing mainly urinary tract infections. Pseudomonas aeruginosa is also very common, chiefly causing lower respiratory tract infections (38). Of great significance is a recent finding that reports that medical tables or hands of the medical staffs which are disinfected daily can be colonized by bacteria (28). Therefore, decontamination of patient care equipment requires the destruction or removal of any organisms present in order to prevent them infecting other patients and health care workers. Bacteria on equipment can gain access though skin lesions, inhalation of infected secretions or by close contact with damaged mucous membranes. The risks are as great in the pre-hospital environment as they are in the hospital setting. This perhaps can explain the reason for isolation of these bacteria in virtually all the equipments examined in this present study.

The antibiotic susceptibility profile of the bacterial isolates present high level of resistance against the antibiotics screened. This study found great insensitivity of Staphylococcus aureus, Enterobacter spp. and Klebsiella spp. against the antibiotics studied, although Klebsiella spp. and Enterobacter spp. were susceptible to Streptomycin. This finding compares to the report of Al-Charrakh (39) in his work on bacterial resistance from oral medication. Also, Obiekezie et al. (29) had demonstrated that bacterial isolates from clinical samples are sometimes more resistant to common antibiotics, they deduced that health care centres which are suppose to be places where people can go to for cure of infectious disease have become a breeding place for antibiotics resistant bacteria in Nigeria and other developing countries because of the ease of transfer of resistant bacteria to other bacteria agents in this environment.

\section{Conclusion}

It was observed that large array of bacteria can colonize the surfaces of hospital equipments thereby posing a risk for the acquisition of nosocomial (hospital acquired) infections. Mostly, the transmission of bacteria from environmental surfaces to patients is largely via hand contact with the surface. This present study isolates E. coli, Klebsiella spp., Pseudomonas spp., Staphylococcus aureus and Enterobacter 
spp. from surfaces of hospital equipments used for various medical procedures in the two hospitals. It is of public health concern that almost all of the surfaces were contaminated with bacteria which can serve as a potential source of crossinfection from the hands of the healthcare workers to the patients. The isolates also showed great resistance to the antibiotics tested and this is absolutely worrisome because the effectiveness of antibiotics for medical application declines when infections that are once easily curable are now regarded as growing threat from the drug-resistant microbial agent of these diseases. Thus the prevalence of antibiotic resistant bacteria is a serious problem with important implications for hospital infection control. Hence the hospital environment is a complicated ecosystem and many interventions are therefore needed for optimal infection control. One of which is the need for more knowledge, better control of sources, disseminating means and resources to help implement techniques to identify and compare pathogens more accurately in hospital laboratories. It is equally important to look at the quality of environment cleaning, execution methods, products, the workers' degree of knowledge about the important of those aspects and the relation with the reduction of hospital acquired infections dissemination. Although hand hygiene is important to minimize the impact of this transfer, cleaning and disinfecting environmental surfaces appropriately is fundamental in reducing their potential contribution to the incidence of healthcare-associated infections. Hence terminal cleaning, disinfection and sterilization are all part of the decontamination process. Decontamination reduces the risks of cross infection and has been shown to extend the useful life of many items. Fundamentally, drug abuse and misuse should be discouraged as literature had shown extensively that they are the major cause of antibiotic resistance. Further possible investigations should include examining the effect of hand antisepsis or decontamination of surfaces in order to determine whether cleaning these potential sources of infection are associated with a reduced incidence of infection in a hospital.

\section{Authors' Contributions}

AMO conceived the research, participated in the sample collection, sample analysis and drafted the manuscript. YAH and AIG help in literature search and laboratory experiment. OJE supervised the laboratory analysis and reviewed the manuscript. All authors read and approved the final manuscript.

\section{Conflict of Interest}

The authors declare no competing interests whatsoever.

\section{Acknowledgements}

We are grateful to the technologists in the Microbiology Laboratory, NSUK for their technical assistance and also to the Health Research Ethics Committee of Federal Medical Centre Keffi that grant ethical clearance for the research.

\section{References}

[1] Dancer, S. J. (2009). The role of environmental cleaning in the control of hospital-acquired infection. J. Hosp. Infect. 73: 378-385.

[2] Otter, J. A., Yezli, S. and French, G. L. (2011). The Role Played by Contaminated Surfaces in the Transmission of Nosocomial Pathogens. Infect. Control Hosp. Epidemiol. 32 (7): 687-699.

[3] Willey, J. M., Sherwood, L. M. and Woolverton, C. J. (2008). Prescott, Harley and Klein's Microbiology, $7^{\text {th }}$ Edn., Mc Graw Hill Companies, New York, USA.

[4] Yusha'u, M., Bukar, A., Aliyu, B. S. and Abdulkareem, A. (2012). Bacterial Contamination of Some Hospital Equipments in Kano, Nigeria. Hamdard Medicus. 55 (3): 3942.

[5] Davies, T. E. and Lowe, I. A. (1999). Environmental Implications of the Health Care Service Sector. Discussion Paper 00-01. October. In; Ferreira de Toledo and Demajorovic, 2006.

[6] Rutala, W. A and Weber, D. J. (2004). Disinfection and sterilization in health care facilities: what clinicians need to know? Clin. Infect. Dis. 39: 702-9.

[7] Ochie, K. and Ohagwu, C. C. (2009). Contamination of X-Ray Equipment and Accessories with Nosocomial Bacteria and the Effectiveness of Common Disinfecting Agents. African Journal of Basic \& Applied Sciences. 1 (1-2): 31-35.

[8] Embil, J. M., Zhanel, G. G., Plourde, J. P. and Hoban, D. (2002). Scissors: a potential source of nosocomial infection. Infectious Control in Hospital and Epidemiology. 23: 147151.

[9] Schwegman, D. (2008). Prevention of Cross Transmission of Microorganisms is Essential to Preventing Outbreaks of Hospital Acquired Infections. Welch AllynSM2988 Rev A. Pp. $1-6$.

[10] El-Mishad, M. A. (2005). Manual of Medical Microbiology and Immunity, $5^{\text {th }}$ Edition. 11 (2): Pp. 6-7.

[11] Inglis, T. J. J. (1998). Microbiology and Infections. Churchill Livingstone, London, UK.

[12] Alvarado, C. J. and Reichelderfer, M. (2000). The 1997, 1998 and 1999 APIC Guidelines Committees. APIC guideline for infection prevention and control in flexible Endoscopy. AJIC. $1-18$.

[13] Fox, M. and Harvey, J. M. (2008). An investigation of infection control for $x$-ray cassettes in a diagnostic imaging department. Radiography. 14 (4): 306-311.

[14] Whittington, A. M., Whitlow, G., Hewson, D., Thomas, C. and Brett, S. J. (2009). Bacterial contamination of stethoscopes on the intensive care unit. Anaesthesia. 64: 620-624.

[15] Jones, J. S., Hoerle, D. and Riekse, R. (1995). Stethoscopes: a potential vector of infection? Annals of Emergency Medicine. 26: 296-299. 
[16] Bernard, L., Kereveur, A., Durand, D., Gonot, J., Goldstein, F. and Mainardi, L. (1999). Bacterial contamination of hospital physicians' stethoscopes. Infection Control and Hospital Epidemiology. 20: 626-628.

[17] Zachary, K. C., Bayne, P. S., Morrison, V. J., Ford, D. S., Silver, L. C. and Hooper, D. C. (2001). Contamination of gowns, gloves and stethoscopes with vancomycin-resistant enterococci. Infection Control and Hospital Epidemiology. 22: $560-564$.

[18] Cohen, S. R., McCormack, D. J., Youkhana, A. and Wall, R. (2003). Bacterial colonization of stethoscopes and the effect of cleaning. Journal of Hospital Infection. 55: 236-7.

[19] Ekrami, A. R., Kayedani, A., Jahangir, M., Kalantar, E. and Jalali, M. (2011). Isolation of common aerobic bacterial pathogens from the environment of seven hospitals, Ahvaz, Iran. Jundishapur Journal of Microbiology. 4 (2): 75-82.

[20] Favero, M. S. and Bond, W. W. (2001). Chemical disinfection of medical and surgical materials. In: Block SS, (ed), Disinfection, sterilization, and preservation, $5^{\text {th }}$ ed. Philadelphia, PA, Lippincott Williams \& Wilkins. Pp. 881917.

[21] Nasarawa Geographical Information Services (NAGIS) (2015). GPS Map of Nasarawa State showing all the Local Government Areas. www.nagis.gov.ng

[22] Cheesbrough, M. (2006). District Laboratory Practice in Tropical Countries, Part II. Cambridge University Press, Cambridge, U.K. Pp442.

[23] Bauer, A. W., Kirby, W. M., Sherris, J. C. and Turck, M. (1966). Antibiotic susceptibilitytestingby a standardized single disk method. Amer. J. Clin. Pathol. 45: 493-496.

[24] CLSI (2018). Performance standards for antimicrobial susceptibility testing, $28^{\text {th }}$ informational supplement M100S28, Wayne, PA, USA.

[25] Lankford, M. G., Collins, S., Youngberg, L., Rooney, D. M., Warren, J. R. and Noskin, G. A. (2006). Assessment of materials commonly utilized in health care: implications for bacterial survival and transmission. American Journal of Infection Control. 34: 258-263.

[26] Levin, P. D., Shatz, O., Sviri, S., Moriah, D., Or-Barbash, A., Sprung, C. L., Moses, A. E. and Block, C. (2009). Contamination of Portable Radiograph Equipment with Resistant Bacteria in the ICU. Chest. 136: 426-432.

[27] Oliveira, A. C. and Damasceno, Q. S. (2010). Surfaces of the hospital environment as possible deposits of resistant bacteria: a review. Rev. Esc. Enferm. USP. 44 (4): 1112-1127.

[28] Garcia-Cruz, C. P., Aguilar, M. J. N. and Arroyo-Helguera, O. E. (2012). Fungal and Bacterial Contamination on Indoor
Surfaces of a Hospital in Mexico. Jundishapur Journal of Microbiology. 5 (3): 460-464.

[29] Obiekezie, S. O., Ndimele, E. C. and Otti, T. A. (2013). Antibiotic Resistance Pattern of Bacteria Species Isolated from Wastewater in Bingham University Clinic, Karu, Nasarawa State, Nigeria. International Journal of Biotechnology and Allied Sciences. 8 (1): 1070-1076.

[30] Mc Donell, A. (2008). Issues of infection control in prehospital settings. Journal of Emergency Primary Health Care. 6 (4): 1-10.

[31] Chacko, I., Jose, S., Isa, A. and Bhat, K. G. (2003). Survival of Nosocomial Bacteria in Hospital Fabrics. International Journal of Medical Microbiology. 21 (4): 291.

[32] Bhalla, A., Drin, D. and Donskey, C. J. (2007). Staphylococcus aureus intestinal colonization in associated with increased frequency of $S$. aureus on skin of hospitalized patients BMC Infectious Diseases. 7 (105): 108-23.

[33] Kayabas, U., Bayraktar, M., Otlu, B., Ugras, M., Ersoy, Y. and Bayindir, Y. (2008). An outbreak of Pseudomonasaeruginosa because of inadequate disinfection procedures in a urology unite: A pulsed- field gel electrophoresis - based epidemiologic study. American Journal of Infections Control. 36 (1): 33-38.

[34] Singh, K., Dar, F. A. and Kishor, K. (2013). Bacterial Contamination in Operating Theatres of District Hospital Budgam in Kashmir Division. Innovative Journal of Medical and Health Science. 3 (2): 62-63.

[35] Cordeiro, L. A. O., Oliveira, M. M. C., Fernandes, J. D., Antunes Barros, C. L. M. and Castro, L. M. C. (2014). Equipment contamination in an intensive care unit. Acta Paul Enferm. 28 (2): 160-165.

[36] Harris, A. D. (2008). "How important is the environment in the emergence of nosocomial antimicrobial-resistant bacteria?" Clinical Infectious Diseases. 46 (5): 686-688.

[37] Kim, J. M., Park, E. S., Jeong, J. S., Kim, K. M., Oh, H. S. and Yoon, S. W. (2000). Multi-center surveillance study for nosocomial infections in major hospitals in Korea. Nosocomial Infection Surveillance Committee of the Korean Society for Nosocomial Infection Control. American Journal of Infectious Control. 28 (6): 454-458.

[38] Richards, M. J., Edwards, J. R., Culver, D. H. and Gaynes, R. P. (1999). Nosocomial infections in medical intensive care units in the United States. National Nosocomial Infections Surveillance System. Critical Care Medicine. 27 (5): 887-92.

[39] Al-Charrakh, A. H. (2012). Frequency and antimicrobial resistance of bacteria isolated from oral and topical medicaments from Hilla, Iraq. Journal of Infections in Developing Countries. 6: 489-94. 